\title{
ROCES ENTRE LA JURISDICCIÓN ECLESIÁSTICA \\ Y LA REAL DURANTE EL EPISCOPADO DE \\ FRAY ALONSO BERNARDO DE LOS RÍOS Y GUZMÁN (1677-1692)
}

\author{
Conflicts between ecclesiastical and royal jurisdiction during \\ the pontificate of Fray Alonso Bernardo de los Ríos y Guzmán
}

(1677-1692)

Recibido: 28-08-2018
Aprobado: $03-11-2020$

MOISÉS LILLO VICENTE*

\section{RESUMEN}

Los desencuentros entre el Arzobispo y la Chancillería de Granada fueron un mal inevitable dado el entramado jurídico del siglo XVII. La competencia entre la jurisdicción eclesiástica y la real se agravó, primero, por el patronato regio sobre la Iglesia de Granada y, segundo, por el ímpetu regalista de muchos oidores al que el arzobispado contestó con un intento de reafirmación de la autoridad episcopal. Esta rivalidad fue evidente en los actos y ceremonias públicas. La silla del arzobispo en la procesión del Corpus fue uno de los símbolos más célebres de este pulso entre ambas instituciones. Su reivindicación fue una forma de subrayar la autoridad del arzobispo y, por ende, la jurisdicción eclesiástica. Pero en la vida de los prelados granadinos jugó un papel más profundo que trascendió la obligación institucional y la soberbia personal.

Palabras clave: Arzobispo; Chancillería; Granada; Alonso Bernardo de los Ríos y Guzmán; jurisdicción real; jurisdicción eclesiástica; siglo XVII.

\section{ABSTRACT}

The disagreements between the Archbishop and the Chancery of Granada were inevitable because of the law in the seventeenth century. The competition between ecclesiastical and royal jurisdiction was aggravated, first, by the royal patronage over the Church of Granada and, second, by the regalist impulse of many judges and the reafirmation of episcopal authority. This rivalry was evident in public acts and ceremonies. The archbishop's chair in the Corpus Christi procession was one of the most celebrated symbols of this struggle between the two institutions. The recognition of the chair was a way to emphasize the authority of the archbishop and, therefore, the ecclesiastical jurisdiction. But in the life of the prelates of Granada, the chair played a deeper role that transcended the institutional obligation and personal pride.

Keywords: Archbishop; Chancery; Granada; Alonso Bernardo de los Ríos y Guzmán; royal jurisdiction; ecclesiastical jurisdiction; $17^{\text {th }}$ century.

\section{LA RIVALIDAD ENTRE EL ARZOBISPO Y LA CHANCILLERÍA}

El establecimiento del Tribunal de la Chancillería en Granada y el patronato ${ }^{1}$ regio sobre su Iglesia son dos circunstancias que marcaron inevitablemente el

* Contratado FPU 16/01502 del Departamento de Historia Moderna y de América de la Universidad de Granada. moiseslillo@ugr.es

1. Sobre la naturaleza del patronato regio consúltese Teófanes Egido López, "El real patronato", en Iglesia y sociedad en el reino de Granada (ss. XVI-XVIII), Eds. Miguel L. López-Guadalupe 
carácter e idiosincrasia de la diócesis granadina y la hicieron más proclive al enfrenamiento con el poder civil. El patronato regio otorgaba plena facultad al monarca sobre los asuntos temporales de la Iglesia de Granada, circunstancia que elevaba las expectativas de obediencia de los arzobispos al poder secular, especialmente al real ${ }^{2}$. Pero los arzobispos granadinos tendieron a mostrar un rechazo sistemático a la Chancillería y, sobre todo, a que este tribunal entendiese en materia de patronato; con el argumento de que solo el rey y su Consejo eran jueces competentes. Si bien, como señala M. L. López-Guadalupe, la Chancillería representaba las prerrogativas reales y, por tanto, estaba perfectamente capacitada para juzgar tales cuestiones ${ }^{3}$. La animadversión entre ambas instituciones surgió como resultado directo de la competencia jurisdiccional, agravada por el hecho de que a menudo las dos potestades concurrían al no existir unos límites claros ${ }^{4}$. La intromisión de la Chancillería en pleitos de la Iglesia de Granada, a veces a instancia de clérigos disconformes con la decisión del ordinario, quebrantaba la inmunidad eclesiástica y mermaba la autoridad episcopal. De igual forma que algunas prerrogativas jurídicas de la Iglesia como, por ejemplo, el refugio de reos a sagrado, entorpecía la aplicación de la justicia por parte de la Chancillería.

El oidor Pedro Golfín de Ulloa representó de forma alegórica esta competencia jurisdiccional en un memorial de fuerte carácter regalista, donde el sol simbolizaba la potestad espiritual y la luna la secular o temporal ${ }^{5}$. Entre otras cosas, aconsejó al monarca que debía designar a los arzobispos más idóneos para regir las iglesias de patronato regio, "porque en poniendo en una mano indiscreta la Monarquía del Sol, para que rija el carro de sus luzes, oyrán lo que, no a despropósito de lo que trata, dixo reprehendiendo Júpiter al Sol" ${ }^{6}$. Ulloa recurrió al mito de Faetón —el malogrado hijo de Helios que no fue capaz de

Muñoz, Antonio Lara Ramos y Antonio L. Cortés Peña (Granada: Universidad de Granada, 2003); Francisco Javier Martínez Medina, "Sacerdocio y Reino en la Edad Moderna. Una Iglesia nacional: el Patronato Regio desde la perspectiva histórica. Una Iglesia nacional”, en Religión y poder en la Edad Moderna, Eds. José L. Beltrán Moya, Antonio L. Cortés Peña y Eliseo Serrano Martín (Granada: Universidad de Granada, 2005).

2. Miguel L. López-Guadalupe Muñoz, "Jurisdicción real y jurisdicción eclesiástica: El "Auxilio de la fuerza" en la Granada del Seiscientos", en Violencia y conflictividad en el universo barroco, Coords. Julián J. Lozano Navarro y Juan L. Castellano (Granada: Comares, 2010), 309.

3. López-Guadalupe, "Jurisdicción real y jurisdicción eclesiástica", 342.

4. José Garrido Arredondo, "Los recursos de fuerza a través de la práctica judicial del siglo XVII en la Chancillería de Granada", en Iglesia y Sociedad en el reino de Granada (ss. XVI-XVIII), Eds. Antonio L. Cortés Peña, Miguel L. López-Guadalupe Muñoz y Antonio Lara Ramos (Granada: Universidad de Granada, 2003), 96.

5. Pedro Golfín de Ulloa, Al rey nuestro señor. Los luminares mayor, y menor, que representan las dos jurisdicciones, y potestades, espiritual, y temporal (Granada: Imprenta Real de Francisco Sánchez, 1670).

6. Golfín, Los luminares, h. 6 r. 
gobernar el carro solar y ocasionó graves daños al mundo-, para avisar de los peligros que puede ocasionar un prelado temerario $\mathrm{y}$, sobre todo, desobediente al poder real. Este memorial no tardó en generar réplica desde el ámbito eclesiástico. Muñoz de Ahumada, tesorero y canónigo de la catedral, retomó el símil astronómico para argumentar justamente lo contrario. Ahumada tildó a la luna, identificada por Ulloa con el poder civil, de "femínea, y no(c)turna, e infesta a los vivientes, si no la templa el aspecto del Sol"7. Y puso el ejemplo del eclipse solar, fenómeno que la tradición relacionaba con todo tipo de males, para mostrar el daño que ocasionaba la intromisión del poder temporal (luna) en los asuntos eclesiásticos (sol).

Esta rivalidad jurisdiccional se convirtió en un mal endémico que alentó el brote, y a veces la perpetuación, de numerosos conflictos en torno a asuntos de la más diversa índole. En estas lides cada institución usó sus armas (las censuras espirituales frente a las multas y hasta suspensión de las temporalidades) y generalmente solo encontraron solución en el fallo del Consejo de la Cámara de Castilla.

\section{LA PROCESIÓN DEL CORPUS COMO CAMPO DE BATALLA}

La rivalidad entre el Arzobispo y los ministros de la Chancillería también alcanzó el terreno de lo protocolario y simbólico. La naturaleza de la sociedad moderna provocaba que los cuerpos privilegiados prestasen una atención minuciosa a la puesta en escena pública por constituir un claro reflejo del rango de poder ${ }^{8}$. Por consiguiente, existieron múltiples disputas sobre esta clase de cuestiones a lo largo de la modernidad ${ }^{9}$. En Granada, su más célebre procesión,

7. Miguel Muñoz de Ahumada, Soberana señora. A vuestra protección D.C.O. El deán, y cabildo de la $S^{\text {ta }}$ Yglesia... sobre los excesos cometidos por algunos Racioneros de dicha Santa Yglesia (Granada: s.n., 1670), h. 105 v.

8. Antonio Luis Cortés Peña, "Un conflicto jurisdiccional en el declive del Santo Oficio", en Iglesia y Sociedad en el reino de Granada (ss. XVI-XVIII), Eds. Antonio L. Cortés Peña, Miguel L. López-Guadalupe Muñoz y Antonio Lara Ramos (Granada: Universidad de Granada, 2003), 189.

9. Los conflictos entre las autoridades religiosas y las seglares por las procesiones en general, y por la del Corpus en particular, fueron una constante en la sociedad moderna. Para más información véanse los trabajos de Félix Leturia Ibarrondo, "Conflicto en Corpus Christi: escándalos ceremoniales o secuencias rituales", Kobie Serie Antropología Cultural, no. 18 (2014); María Jesús Sanz, "La procesión del Corpus en Sevilla. Influencias sociales y políticas en la evolución del cortejo", Ars longa: cuadernos de arte, no. 16 (2007): 60; Milagros León Vegas, "Rivalidad de preeminencias entre el cabildo civil y eclesiástico en los cortejos procesionales del Corpus Christi. Antequera (siglo XVI)", en Poder, sociedad, religión y tolerancia en el mundo hispánico, de Fernando el Católico al siglo XVIII, Coords. Eliseo Serrano Martín y Jesús Gascón Pérez (Zaragoza: Institución Fernando el Católico, 2018), vol. 2. 
la del Corpus ${ }^{10}$, se convirtió en asiduo campo de batalla entre ambas instancias, y requirió el constante despacho de cédulas reales.

El pleito granadino, que se prolongó durante más de un siglo, giraba en torno al uso de una silla, una almohada y una salvilla con lienzo por parte del arzobispo durante el recorrido procesional; elementos que portaba un nutrido grupo de pajes. Los ministros de la Chancillería, que proseguían al prelado en la comitiva procesional, se quejaban de que la silla les entorpecía la vista de la Custodia e insistían en su supresión por ser una práctica ostentosa opuesta al ceremonial romano. Pero lo que realmente irritaba a la Chancillería era que el prelado se sentase en presencia del presidente y los oidores (y, además, de espaldas a ellos), quienes, constituidos en Real Acuerdo, representaban al propio monarca. Por su parte, los arzobispos alegaban que se trataba de una costumbre inmemorial aprobada por la sede apostólica, muy estimada por el pueblo, y que formaba parte de la dignidad arzobispal granadina.

Ambas instituciones respaldaron su opinión preocupándose por el ejemplo que se daba a la población. Los oidores consideraban la ceremonia una muestra de vanidad opuesta a la humildad cristiana, mientras que los prelados, una excelente manera de manifestar la grandeza de la eucaristía ${ }^{11}$. La Corona era del mismo parecer que la Chancillería, y así lo expresó en la cédula de mayo de 1669.

Puede que la alusión al pueblo solo fuera un pretexto, pero lo cierto es que tanto al Arzobispo como a los ministros de la Chancillería les preocupaba el concepto que la sociedad tuviera de ellos. Ambas instituciones siempre se esforzaron en proyectar a la población una imagen concreta de sus respectivas dignidades con el objetivo de lograr el máximo reconocimiento popular y remarcar su prestigio. No en vano, el presidente de la Chancillería estaba sujeto a un estricto protocolo encaminado a exaltar su figura como máximo representante de la autoridad real ${ }^{12}$. Por ello, Lobatón y Sarmiento, fiscales de la Chancillería, lamentaban la merma de autoridad que suponía que estuviera "movido todo el Pueblo, para ver si [el arzobispo] se atrevía a desobedecer, o obedecer las Reales Ordenes" 13 .

10. Sobre la pompa y significación de la fiesta sacramental consúltese José Jaime García Bernal, El fasto público en la España de los Austrias (Sevilla: Universidad de Sevilla, 2006), 281-285.

11. A propósito, el arzobispo Diego Escolano consideraba que "la virtud, y la santidad se dan muy bien las manos con el lustre, gloria, y authoridad". Diego Escolano y Ledesma, Memorial a la reyna nuestra señora. Por don Diego Escolano... sobre el uso de la silla en la processión del Corpus (Granada: s.n., 1669), h. 23 r.

12. Inés Gómez González, "El ceremonial de la justicia en la Granada del setecientos", en Vida cotidiana en la España de la Ilustración, Coord. Inmaculada Arias de Saavedra Alías (Granada: Universidad de Granada, 2012), 314.

13. Diego Ximénez Lobatón y Pedro Sarmiento y Toledo, Señor. A los reales pies de V.M. ponen este discurso jurídico... sobre no aver cumplido D. Diego Escolano, arzobispo de esta ciudad, las reales cédulas de V.M. en que se le mandó no sacasse silla, almoada, y salvilla en la processión del día del Corpus (Granada: ex Typographia Regia, 1670), h. 19 v. 
Una adecuada comprensión del pleito obliga a repasar brevemente sus vicisitudes hasta la llegada del arzobispo Ríos y Guzmán. Como apunta Gan Giménez, parece ser que el arzobispo Pedro Guerrero (1546-1576) usó la silla sin problema y que los conflictos comenzaron con Pedro de Castro y Quiñones (1589-1619) ${ }^{14}$. La cédula de 7 de mayo de 1607 decretó que Castro no usase silla en las procesiones realizadas dentro de la iglesia y que en caso de ser necesaria la llevase apartada. El arzobispo Martín Carrillo de Alderete (1641-1653) sacó la silla apartada a un lado en 1647, pero esta rompió el claro en algunas calles estrechas, lo que suscitó el malestar de la Chancillería. Una nueva cédula en 1649 insistió en que la silla no ocupase el núcleo procesional, incluso cuando el arzobispo se sentase. En 1658 el arzobispo José de Argáiz (1654-1667) logró el apoyo del primado de Toledo, Baltasar de Moscoso y Sandoval, cesando temporalmente la controversia. En 1669, la reina gobernadora, Mariana de Austria, prohibió su uso. Sin embargo, el arzobispo Diego Escolano (1668-1672) hizo caso omiso, por lo que fue multado y obligado a comparecer en Madrid (aunque, finalmente, ambas sanciones fueron suspendidas). Y a pesar de los esfuerzos de Escolano, la cédula de mayo de 1670 volvió a ratificar la prohibición, permitiendo únicamente que el arzobispo tuviera silla en los altares ante los que paraba la procesión, siempre y cuando no diese la espalda a la Chancillería.

Esta fue la principal cédula que la Chancillería entregó al arzobispo Ríos y Guzmán dos días antes del Corpus de 1678. Sin embargo, como veremos, el nuevo prelado se las ingenió para que la silla fuera en el recorrido de la procesión.

Tenemos que tener en cuenta que el patronato regio implicaba que la Iglesia de Granada estuviera más amenazada por las ideas regalistas, patentes en destacados ministros de la Chancillería como, por ejemplo, Diego Ximénez Lobatón. De modo que la defensa de la silla se convirtió en un símbolo de resistencia de la inmunidad eclesiástica y de la autoridad episcopal. A la luz de este pulso debemos interpretar este tipo de comportamientos provocadores, como, por ejemplo, la decisión de Ríos y Guzmán de sacar la silla, o que Diego Escolano, a pesar de la prohibición de 1669 , se sentase "no una, o dos vezes, sino seys, siendo la primera a la puerta de la Iglesia, donde no podía ir muy cansado (y más no haviendo aquel día celebrado de Pontifical) y no guardarlo en lo explícito, que es llevar la Custodia en las manos" ${ }^{15}$. Estas conductas desafiaban tanto a los oidores como al propio poder real; de hecho a Escolano no le tembló el pulso para recordar a la reina que le faltaba potestad, por tratarse de un asunto espiritual tocante a ceremonia, y que "introducirse en este conocimiento en quanto no es permitido, no solo es peligroso, sino condenable" ${ }^{16}$.

14. Pedro Gan Giménez, "En torno al Corpus granadino del siglo XVII", Chronica nova: Revista de historia moderna de la Universidad de Granada, no. 17 (1989): 95.

15. Lobatón y Sarmiento, Señor. A los reales pies, h. 23 r.

16. Escolano, Memorial a la reyna, h. 6 r. 


\section{LA DEFENSA DE LA SILLA: ¿OBLIGACIÓN IMPRESCINDIBLE PARA UN PRELADO GRANADINO?}

Pero, ¿el interés de los prelados se limitaba realmente al lustre de la dignidad arzobispal? El memorial de 1684 que mandó escribir Ríos y Guzmán en defensa de la silla sostiene que "este es empeño del Arçobispo, porque le toca su defensa, no por sí, que vive sin vanidad, y en la humildad de Religioso, que professa" ${ }^{17}$. No obstante, dos cartas que escribió el arzobispo a su hermano evidencian motivos más profundos que posibilitan una nueva lectura del asunto de la silla. Con bastante probabilidad, el destinatario sea Don Lope de los Ríos y Guzmán, presidente de la Chancillería de Granada (1662-1666) y más tarde del Consejo de Hacienda, pues el arzobispo le suplica su intercesión ante el resto de ministros de la Corte y, además, se conservan varias cartas del propio Don Lope en las que aconseja a su hermano sobre este negocio.

La confianza y el carácter privado de las misivas llevaron a que Ríos y Guzmán expresase abiertamente sus temores y criticase a los oidores y a algunos de sus predecesores. Mientras que la Chancillería alabó la prudencia del arzobispo anterior, el cisterciense Francisco Rois y Mendoza (1673-1677), catalogando su obediencia de "acción digna de imitarse y de envidia christiana" ${ }^{18}$, Ríos consideró que el desentendimiento de Rois fue una insensatez que le valió la consideración de pusilánime. En este orden de cosas, el prelado escribió:

y pensar que a de haver Arzobispo de Gran ${ }^{\mathrm{da}}$ que salga dos vezes sin silla es pensar un imposible, la primera vez puede ser que con poca prudencia o no sabiendo lo que haze se exponga al peligro como le suçedió al Arpo Rois, pero haviendo experimentado las afrentas que reçive en su cara y la desestimaçión y despreçio con que le miran ninguno (h)a de asegundar sino es morirse como le suçedió al dho Arzobispo de quien en lo mucho ni en lo poco no se hiço caso desde aquel día pareçiendoles hombre sin valor sin resoluçión y sin fundam ${ }^{\text {to }} \mathrm{y}$ diçiendole en la prozessión no solo las mujeres y muchachos sino los hombres mill libertades y que si no quería silla se pusiese una albarda, y mejor era que estubiera en su conv $v^{\text {to }}$ siendo portero pues no sabía ser Arpo y a(h)ora quando entran en la sala donde están los Arzobispos en esta casa, y miran su retrato, no son pocas las pesadumbres que le dizen, mire VSI con esto quien havia de salir

17. Melchor de Cabrera Núñez de Guzmán, Manifiesto en que el ilustríssimo señor don fray Alonso Bernardo de los Ríos y Guzmán, Arçobispo de Granada, funda, que el llevar en la processión del día del Corpus silla, almohada, y lienço, con la Familia necessaria, y ocupar el claro frente de la Custodia, y Tabernáculo, es ceremonia observada de tiempo inmemorial (Madrid: s.n., 1684), h. $3 \mathrm{v}$.

18. Archivo Eclesiástico de la Curia de Granada [en adelante AECG], Libros de Archivo, Caja 35, Silla, s.f. La Chancillería al rey, 21 de junio de 1678.

Chronica Nova, 46, 2020, 281-308 - http://doi.org/10.30827/cnova.v0i46.7878 
el día del Corpus sin silla y así el quitársela es lo mismo que echarlo de Granada y de la proçessión para siempre ${ }^{19}$.

Estas líneas establecen una clara relación entre el descuido del asunto de la silla y la pérdida de la autoridad y el respeto como prelado. Así, parece que los arzobispos tuvieron en la silla un interés personal que fue más allá de la preocupación institucional y de la mera soberbia personal. La procesión del Corpus suponía una auténtica puesta en escena de los prelados ante la sociedad granadina, y, por ende, la ocasión ideal para lograr buena imagen entre el pueblo y el clero granadino.

Los memoriales insisten en que uno de los motivos por los que los arzobispos reivindicaban la silla era para complacer a la población, la cual estimaba enormemente su presencia en la procesión. A propósito, Diego Escolano señalaba:

según lo pío, y religioso de la gente, y estar en inteligencia, se quiere quitar a la Dignidad Arçobispal la mayor grandeza que tiene, y que esto se obra contra lo dispuesto, y acordado por la Sede Apostólica, e inconcuso estilo de esta Iglesia; y assi lo llevan tan agriamente, que no es dezible (...) llegando a tal excesso de passión, que por conservar al Prelado en esta preeminencia, darán las haziendas, y vidas; con que cada año que esto se controvierte, se inquietan, y desaçonan, y ponen a todos los que intervienen en esta materia en cuydado ${ }^{20}$.

Es complicado determinar hasta qué punto importaba este asunto a la población seglar en un siglo tan convulso marcado por la crisis. En concreto, el inicio del episcopado de Ríos coincidió con una epidemia de peste a la que siguieron duros años de carestía. Según Echeverría, cuando Ríos llegó a Granada en febrero de 1678, "ya se manifestaban los ordinarios sustos, y las congojas, y opresiones, que suelen ser precursores de los mortales contagios" ${ }^{21}$. La epidemia estalló definitivamente en 1679, y Echevarría asegura que el arzobispo socorrió a los granadinos "por todos los medios imaginables" 22. Esta coyuntura propició el recurso a los remedios espirituales (novenarios, rogativas, procesiones...) y disparó el fervor popular a sus cotas más altas ${ }^{23}$. Por tanto, la actitud de la gente

19. AECG, Libros de Archivo, Caja 35, Silla, s.f. El arzobispo Ríos a su hermano (fecha desconocida).

20. Escolano, Memorial a la reyna, hh. 33 v-33 r.

21. Juan de Echeverría, Paseos por Granada y sus contornos, ó descripción de sus antigüedades y monumentos, dados a luz por el célebre Padre Juan de Echevarría, por los años de 1764 y ahora nuevamente reimpresos é ilustrados con algunas pequeñas notas (Granada: Imprenta Nueva de Valenzuela, 1814), 412.

22. Echeverría, Paseos por Granada y sus contornos, 412.

23. Como ejemplo ilustrativo, el 26 de junio de 1679, tras una función de rogativa, se vio entre las cejas de la imagen de la Virgen del Rosario una luz en forma de estrella que perduró sesenta 
hacia el tema de la silla debió bascular entre quienes, por un lado, temieron que la indignación del estado eclesiástico agravara la cólera divina, y quienes, por otro, percibieron los roces como un mero entretenimiento que añadía un interés adicional a la procesión. La indiferencia de Rois y Mendoza difícilmente pasó desapercibida entre la población, pero resultan, cuanto menos, exagerados y fruto de una visión subjetiva, los supuestos improperios que cuestionaron su valía como prelado de forma tan descarada.

En cuanto al clero granadino, Gan Giménez señala que el cabildo catedralicio no tenía un interés tan directo en el pleito de la silla como lo podía tener el arzobispo $^{24}$. No obstante, reconoce que el cabildo siempre apoyó a los arzobispos en este asunto ${ }^{25}$. Al fin y al cabo, el prelado era la cabeza del cuerpo eclesiástico y cualquier desdoro de su figura afectaba al prestigio de la archidiócesis en su conjunto. Una clara evidencia del consabido interés del cabildo catedralicio en la silla es que en 1670 el oidor Ulloa acusó a los canónigos de instigar a Diego Escolano en diversas controversias, entre ellas la de la silla, antes de que este llegase a Granada ${ }^{26}$. A lo que Ahumada replicó:

por cartas no se podrá verificar, que el Arçobispo fuesse instigado de ningún Prebendado, ni de el Cabildo, siendo un acto increíble, instigar a su Prelado a semejantes intentos, antes de verle, y conocerle, y que tomasse la possession de su Iglesia. Ni tampoco pudo ser a boca la instigación; porque hasta entrar en Granada, no vio el Arçobispo a algún Prebendado ${ }^{27}$.

Resulta perfectamente comprensible que los clérigos esperasen la implicación de sus prelados en un negocio que la diócesis de Granada llevaba defendiendo tantos años. Por ello, la voluntad pacífica de Rois y Mendoza, que fue en la procesión con capa consistorial y sin silla, debió interpretarse como un desamparo de la jurisdicción eclesiástica y, sobre todo, como un acto de cobardía ${ }^{28}$.

días y se interpretó como una señal divina que anunciaba el fin de la epidemia. Miguel L. LópezGuadalupe Muñoz, "Cofradías y devociones populares en el convento de Santa Cruz la Real de Granada", Revista de Humanidades, no. 27 (2016): 145-148.

24. Pedro Gan Giménez, "Los prebendados de la Iglesia granadina: una bio-bibliografía", Revista del Centro de Estudios Históricos de Granada y su Reino, no. 4 (1990): 158.

25. Pedro Gan Giménez, "Aspectos de la iglesia granadina en el siglo XVII", en Andalucía Moderna: actas del II Congreso de Andalucía (Historia Moderna I), Coord. Instituto de Historia de Andalucía (Córdoba: Publicaciones de la consejería de cultura de la Junta de Andalucía y obra social y cultural Cajasur, 1995), 434.

26. Golfín, Los luminares, h. $54 \mathrm{v}$.

27. Ahumada, El deán y cabildo, h. $111 \mathrm{r}$.

28. El cercano recuerdo de la censura regia a Escolano y, quizás, una verdadera voluntad de apaciguar los ánimos después de tantos años de litigio entre la Chancillería y el Arzobispado, podrían explicar su desentendimiento del tema de la silla. Lo cierto es que Rois y Mendoza, antes de pasar a Granada, convocó un sínodo como obispo de Badajoz en 1671 que abordó de forma minuciosa todos y cada uno de los aspectos de la diócesis. Las constituciones de este sínodo fueron impresas: 
En definitiva, la controversia de la silla, nacida del choque entre la jurisdicción eclesiástica y la civil, se convirtió en una excelente oportunidad para que los arzobispos demostraran su denuedo y capacidad de liderazgo ante la práctica totalidad de la sociedad granadina que acudía a la procesión. Se trataba de una carta de presentación y de una declaración de intenciones en toda regla. Es posible que en cierto modo los arzobispos se sintieran obligados a satisfacer una serie de expectativas de la Iglesia de Granada, entre las que se encontraba el asunto de la silla. Pero su interés principal, más que congraciarse con la diócesis, fue manifestar su valía como obispos para así afianzar el respeto de sus súbditos y del pueblo. Este comportamiento, más que arrogancia, denota un afán por amoldarse al arquetipo de prelado perfecto presente en la tradición eclesiástica y en el imaginario popular. El obispo era el pastor que guiaba a su rebaño, cierto, pero también debía reunir las aptitudes necesarias para defenderlo. A propósito, el oidor Ulloa traía a la memoria en su opúsculo el ejemplo de san Carlos Borromeo, arzobispo de Milán del siglo XVI, para criticar su encendida defensa de la autoridad eclesiástica e intransigencia hacia las autoridades civiles ${ }^{29}$. Mientras que el canónigo Muñoz de Ahumada, precisamente por "el zelo, y acierto de sus actos en defensa de la inmunidad, y jurisdicción de su Iglesia, y Dignidad" ${ }^{30}$, consideraba al milanés un ejemplo de prelado perfecto que, no en vano, la Iglesia canonizó y gozó de gran devoción popular. Efectivamente, este era el prototipo que la Iglesia aplaudía y resulta lógico que fuera el espejo en el que muchos obispos se miraron.

La defensa de la silla era una oportunidad para demostrar tales competencias. Y, además, se trataba de un privilegio que afectaba directamente a la institución mitrada, lo que, evidentemente, suponía un aliciente. Muchos prelados granadinos se emplearon a fondo en este asunto a lo largo de su pontificado, prefiriendo no asistir a la procesión antes que salir sin ella y llegando a pasar largas temporadas en la Corte para lograr su aprobación. Así explicó Ríos su rotunda determinación:

aunque la obed ${ }^{\mathrm{a}}$ que los prelados deben a S. Magd es igual a la de todos sus vasallos, está primero el alma, la honrra, y el crédito, y todo lo perdiera, el que absolutam $^{\text {te }}$ dejara caer, esta ceremonia, y assí quando los prelados no (h)an podido vençer esta dificultad, se retiran, y el prelado siguiente buelbe a suscitar el neg ${ }^{\circ}$, y de esta suerte dura, y durará toda la vida ${ }^{31}$.

Constituciones promulgadas por el ilustrmo y rever ${ }^{m o}$ señor D. Fr. Francisco de Roys y Mendoza... obispo de Badajoz, electo arzobispo de Granada ... en la santa synodo que celebró dominica de sexagésima, primero de Febrero de 1671 años (Madrid: impreso por José Fernández de Buendía, 1673).

29. Golfín, Los luminares, h. 52 r.

30. Ahumada, El deán y cabildo, h. 108 r.

31. AECG, Libros de Archivo, Caja 35, Silla, s.f. El arzobispo Ríos a su hermano, 17 de junio de 1678. 


\section{RÍOS Y GUZMÁN ANTE EL CORPUS DE 1678}

Alonso Bernardo de los Ríos y Guzmán nació en Córdoba en 1626 en el seno de una familia acomodada, vinculada al Condado de Fernán Núñez, que obtuvo en 1680 el Condado de Gabia ${ }^{32}$. Muy joven ingresó en el convento de los trinitarios calzados de Córdoba y tras su formación eclesiástica alcanzó fama de predicador y emprendió una exitosa carrera eclesiástica. Fue superior de los conventos de Baeza, Úbeda y Córdoba, provincial de Andalucía y visitador apostólico. En 1668 fue nombrado obispo de Santiago de Cuba, en 1671 de Ciudad Rodrigo y en 1677, cuando rondaba los cincuenta y un años, arzobispo de Granada ${ }^{33}$.

Ríos y Guzmán entró en Granada el 6 de febrero de 1678, cuatro meses antes de que la ciudad celebrase sus populares fiestas del Corpus. Si el pleito de la silla había permanecido en letargo durante el episcopado de Rois, el nuevo arzobispo desataría de nuevo la polémica en su primer Corpus al frente de la iglesia de Granada.

La respuesta que Ríos dio al secretario del Acuerdo acerca de las cédulas que la Chancillería le entregó tres días antes del Corpus fue del tenor siguiente:

que dhas rreales cedulas no hablan con su yll ${ }^{\text {ma }}$ sino solamente con los $\mathrm{ss}^{\text {res }}$ don $\mathrm{D}^{\circ}$ escolano y don fray Fran ${ }^{\text {co }}$ de rroyz y mendoça y no con los que les suçedieren en la dignidad $=\mathrm{y}$ sin envargo por lo mucho que desea no exceder un punto de las órdnes de su magd si la yndisposiçion y dolor de zeatica que padece le diere lugar a yr este año en la procesión del día del corpus usará de la silla axustandose en todo quanto fuere posible a el tenor de la çedula de la rreyna nra señora despaçhada a catorçe de mayo de myll y $\operatorname{ses}^{\mathrm{o}}$ y setenta en que se le permite a dho sr don diego escolano usar de la silla para descansar en las paradas que fiçiere la custodia del ss ${ }^{m o}$ sacramento con tal que no la llevasse en la procesión ${ }^{34}$.

Por el momento, el arzobispo aseguraba la continuidad de la concordia. Así, en la procesión del 9 de junio, Ríos redujo la familia a dos capellanes y un caudatario, prescindió del paje con salvilla y lienzo, y se sentó en los altares sin volver la espalda al Real Acuerdo. Sin embargo, cuatro pajes transportaron la silla y la almohada ante los atónitos ojos de los oidores por todo el recorrido procesional. Eso sí, apartada a un lado, fuera del claro. Pero esta colocación,

32. Antonio L. Cortés Peña, "Fray Alonso Bernardo de los Ríos y Guzmán, un arzobispo del Barroco", Boletín de la Real Academia de Córdoba de Ciencias, Bellas Letras y Nobles Artes, no. 154 (2008): 206.

33. Miguel A. López, Los arzobispos de Granada. Retratos y semblanzas (Granada: Arzobispado de Granada, 1993), 179.

34. AECG, Libros de Archivo, Caja 35, Silla, s.f. El arzobispo Ríos al escribano del Real Acuerdo, 7 de junio de 1678 [énfasis añadido].

Chronica Nova, 46, 2020, 281-308 - http://doi.org/10.30827/cnova.v0i46.7878 
indicada en algunas cédulas, había sido revocada por la última de 1670; la cual, como se ha visto, prohibía explícitamente el uso de la silla en la procesión. No obstante, el arzobispo nunca reconoció haber quebrantado la cédula, ya que, con mucha astucia, sostuvo que llevar la silla fuera del claro implicaba que no fuera en la procesión.

Esta explicación no convenció a los oidores, quienes el día 21 de junio informaron al monarca de lo sucedido, lamentando la mortificación que les provocaban "las vozes que oian de algunos (...) con el gozo de ver en parte aj(a)da su autoridad que por no imaginada causó más alvorozo" ${ }^{35}$. En efecto, tras el malogrado esfuerzo de Escolano y el desistimiento de Rois, tanto el pueblo como la Chancillería debieron sorprenderse de ver de nuevo la silla en la calle. Asimismo, alegaron que se trataba de un atropello a la autoridad de un tribunal "que tanto nezesita de la estimaçion y maior autoridad para la buena administración de justicia de tantos reinos".

El arzobispo, resentido por el rumor de que el Acuerdo le iba a imponer una multa, se desahogó con su hermano en una misiva y criticó duramente a los oidores:

que los más de ellos son unos muchachos que ayer salieron de los colejios y aunque todos juntos tienen la beneraçion y se les deve respecto que es notorio ni este (h) a de ser mayor que el que se le tiene al rei $(\ldots)$ es opinión de estos ${ }^{\text {res }}$ que para que el pueblo los venere y entiendan lo que pueden y que los andaluzes que es jente engreída teman este tribunal combiene hazer ruido atropellar al arzobispo entrar en su casa rejistrarsela buscar el dinero o la plata que tuviere y si no la tuviere sacar aunque sea unas sillas viejas ${ }^{36}$.

También informó a su hermano de que la Chancillería estaba reuniendo papeles para probar su razón, por lo que "combiene mucho que se le atajen los pasos a estos yntentos". Ríos y Guzmán era consciente de que había reabierto el viejo litigio con los oidores y pensaba hacer todo lo posible para salir victorioso. Para empezar, escribiría a Juan José de Austria, a los señores del Consejo, a algunos obispos y al confesor regio.

El recurso al confesor real era fundamental por la afinidad que podía suscitar su condición eclesiástica y, sobre todo, por la gran influencia que tenía sobre la conciencia del monarca. Ante la actitud belicosa de la Chancillería, Ríos adoptó un discurso radical. Sí, se arrepentía de haber llevado la silla apartada "fuera" de la procesión, pero no por haber infringido la cédula, sino porque la silla no ocupó el lugar que realmente le correspondía: el claro de la procesión.

35. AECG, Libros de Archivo, Caja 35, Silla, s.f. La Chancillería al rey, 21 de junio de 1678.

36. AECG, Libros de Archivo, Caja 35, Silla, s.f. El arzobispo Ríos a su hermano (fecha desconocida). 
Este talante apasionado puede apreciarse en la súplica que dirigió al confesor regio en junio de 1678:

solo el recurso a S. mag ${ }^{d}$ por medio de la representaçion de VS pudiera templar la aflicçion y desconsuelo en que me veo considerando que io (h)e sido el que (h)e dejado perder (aunque solo por esta vez y con pretexto de no perjudicar la dign $^{\mathrm{d}}$ lo que por tantos a(ños) defendieron mis anteçesores ${ }^{37}$.

En la misma carta señaló que la Chancillería había esperado cuidadosamente a que se aproximase el Corpus para entregarle la cédula con el fin de que no tuviera tiempo para recurrir al monarca. También manifestó la pesadumbre que le causaba que, a pesar de su "obediencia", los oidores continuasen insistiendo en que no llevase silla o que tuviese tantas como paradas. Esta alternativa, ya contemplada en la cédula de 1670 , se trataba de una medida bastante práctica que podía dar al traste con los planes del prelado, por lo que se esmeró en desacreditar esta opción a ojos del padre confesor:

y obligarle a que tenga muchas sillas puestas en todos los sitios donde se ubiere de parar, no solo es despojarle, sino imponerle una oblig ${ }^{\text {on }}$ costosa y estrabagante, y privarle de poder usar de la silla si se ofreçiere algún acçidente impensado a su salud, como es posible y (h)a sucedido algunas veçes por ser la proçesion muy dilatada, el tiempo de grandes calores, e ir revestido de pontifical, y preçisarlo a que ponga criados que guarden la silla en todas las partes donde estubiere (porque no se sienten en ella los seglares, o haga el pueblo irritado contra el Arpo alguna indecencia) lo qual ya se ve que es inpracticable ${ }^{38}$.

En febrero de 1679 volvió a escribir al confesor regio insistiendo en la importancia de su apoyo "siendo esta causa de relixion, y p(o)r consiguiente muy immediata a la conciencia de S.Mag ${ }^{\mathrm{d}}{ }^{39}$. Entre otras cosas, le avisó de los alborotos populares que traería consigo la prohibición de la silla, especialmente en un momento tan delicado marcado por los rigores de la peste y el hambre. Ríos dejó constancia de que estaba dispuesto a hacer todo lo posible para lograr su propósito. Y, desde luego, sabía que la solución más efectiva era tratar el asunto de forma personal en la Corte.

El principal apoyo del arzobispo en la Corte fue su hermano don Lope, quien aprovechó su posición en el gobierno de Madrid para allanarle el camino.

37. AECG, Libros de Archivo, Caja 35, Silla, s.f. El arzobispo Ríos al confesor regio, junio de 1678 .

38. AECG, Libros de Archivo, Caja 35, Silla, s.f. El arzobispo Ríos al confesor regio, junio de 1678.

39. AECG, Libros de Archivo, Caja 35, Silla, s.f. El arzobispo Ríos al confesor regio, 20 de febrero de 1679 . 
Desde el principio, Don Lope alentó a su hermano a que defendiese la dignidad arzobispal. Así lo dejó sentir en una carta:

soy del mismo sentir que VSI en las materias de la jurisdiçion eclesiástica, y estoy muy lexos de pensar que VSI dexe de cumplir muy exactam ${ }^{\text {te }}$ con todo lo que mirare a las obligaciones de su dignidad y jurisdiçion como se debe ${ }^{40}$.

Don Lope informaba al prelado de cada novedad, de las personas con las que trataba el asunto y, por supuesto, lo asesoraba según evolucionaban los acontecimientos. Por estas fechas, Don Lope se mostraba optimista y confiaba en la conveniente resolución del pleito. Al menos, eso decía a su hermano a principios de marzo de 1679:

en quanto al negoçio de la silla me pareze bien la forma en que VSI a buelto a escribir a estos $\mathrm{ss}^{\text {res }}$ del conss $^{\circ}$ sobre esta materia (h)e hablado a S. A y a Don $\mathrm{Ger}^{\mathrm{mo}}$ de Eguia y han hecho otras diligenzias, y tengo mucha esperança de que (h)a de tener buen suzesso, y lo que yo quisiera es que VSI no tomasse desazon ni inequietud alguna por este negoçio y (...) que por ahora no se mueba cossa alguna y permita que aca gobernemos esta materia ${ }^{41}$.

La situación exigía astucia y en dicha misiva le propuso una sutil artimaña. Se trataba de que el arzobispo escribiese al nuncio con el pretexto de no poder recurrir a Roma ante la inminencia del Corpus, y le solicitase licencia para asistir a la procesión sin silla. Don Lope estaba seguro de que el nuncio, viendo las resoluciones del pontífice y de la congregación de ritos, sería incapaz de dársela. Evidentemente, no pretendía que se despachase tal licencia, simplemente se trataba de una argucia para, llegado el momento, tener una prueba irrefutable de que los esfuerzos del arzobispo no respondían a intereses particulares, sino solo a su obediencia a Roma.

Sin embargo, la cédula real de 27 de abril de 1679 supuso un hachazo a las pretensiones del arzobispo. El monarca determinó que Ríos había infringido la cédula. Y esta vez, para no dejar resquicio de duda, la resolución fue más explícita todavía:

no llevéis la silla por las calles por donde fuere la proçession sino por otras o que baya delante de un sitio a otro de los en que ubiereis de parar o que en cada uno tengáis una silla prevenida para este efecto lo que elixiereis por más conveniente ${ }^{42}$.

40. AECG, Libros de Archivo, Caja 35, Silla, s.f. Lope de los Ríos al arzobispo Ríos, 21 de febrero de 1679.

41. AECG, Libros de Archivo, Caja 35, Silla, s.f. Lope de los Ríos al arzobispo Ríos, 7 de marzo de 1679 .

42. AECG, Libros de Archivo, Caja 35, Silla, s.f. Cédula del rey al arzobispo Ríos y Guzmán, 27 de abril de 1679 [énfasis añadido]. 
Ahora sí, la silla quedaba excluida definitivamente de la procesión. El 23 de mayo de 1679 el arzobispo acató la orden ante el secretario del Real Acuerdo, garantizando que procuraría ajustarse a alguno de los tres modos que señalaba la cédula. No obstante, disculpó su probable indisposición debido al fuerte dolor de ciática y aprovechó para suplicar al monarca "sea servido de mandar que la dignidad arçobispal sea oída en justicia en el tribunal o tribunales que deban" ${ }^{43}$. Con esta respuesta, Ríos y Guzmán dejaba claro que no iba a darse por vencido tan fácilmente y que la guerra no había hecho más que comenzar.

\section{EL PASO DE RÍOS Y GUZMÁN A LA CORTE}

En 1684, el arzobispo volvió a la carga con el ya citado manifiesto escrito por Melchor de Cabrera Núñez de Guzmán, abogado de los Consejos, en el que fundaba la ceremonia de la silla. Melchor de Cabrera estaba familiarizado con la diócesis de Granada, pues ya había escrito dos memoriales a favor de Diego Escolano en el pleito que mantuvo con los racioneros de la catedral en $1670^{44}$. El manifiesto de 1684 se divide formalmente en cuatro partes, a las que precede una relación del litigio. Como cabría esperar, se repiten argumentos de memoriales anteriores, incluso fragmentos literales, pues a estas alturas existía abundante información sobre el particular. El primer capítulo intenta probar que el Real Acuerdo no es parte de la procesión porque no asiste por obligación, "no es llamada, ni combidada, llévala su devoción a dar exemplo al Pueblo, y presidirle (...) ni la Iglesia, ni la Ciudad la dan velas" ${ }^{45}$. El segundo capítulo remonta la ceremonia a la época del obispo San Cecilio (siglo I) y aporta los testimonios de otras iglesias españolas donde todavía se practica, como son Toledo, Sevilla, Burgos, Barcelona y Cuenca. En tercer lugar, se insiste en que la silla debe ocupar el claro de la procesión, pues

faltando, o apartándose el Arçobispo, los dos claros se reducirán a solo uno, a que presidirá el Presidente de la Chancilleria, y sus Ministros inferiores (...) quién no atribuirá a indecencia lo uno, y lo otro, viendo un seglar (aunque de la mayor Dignidad) ocupar el lugar ${ }^{46}$.

43. AECG, Libros de Archivo, Caja 35, Silla, s.f. El arzobispo Ríos al escribano del Real Acuerdo, 21 de mayo de 1679.

44. Melchor de Cabrera Núñez de Guzmán, Verdades averiguadas en favor de la justicia, y autoridad del ilustrissimo señor D. Diego Escolano... (Madrid: Imprenta de Domingo García Morrás, 1670); Demostración canónica, legal, histórica, y política, que reducida a Memorial... (Madrid: Imprenta de Domingo García Morrás, 1670).

45. Cabrera, Manifiesto en que el ilustríssimo señor don Fray Alonso Bernardo de los Ríos, h. 29 v.

46. Cabrera, Manifiesto en que el ilustríssimo señor don Fray Alonso Bernardo de los Ríos, h. 80 v. 
Por último, el cuarto capítulo recuerda que la ceremonia está confirmada por la sede apostólica por dos breves de Alejandro VII y Clemente X.

El 20 de junio de 1685, víspera del día del Corpus, el prelado aprovechó un acontecimiento acaecido el año anterior para reafirmar su pretensión ante el secretario del Real Acuerdo. Resulta que en 1684 el nuncio papal, el Cardenal Millini, había comunicado a la iglesia española la orden del pontífice de que el Santísimo se llevase en las manos y no en andas ${ }^{47}$. Así, Ríos y Guzmán halló nuevos motivos para justificar la ceremonia de la silla. Si ya se había repetido hasta la saciedad que el arzobispo representaba la majestad de Cristo en la procesión, ahora se daba un paso más, pues

por la ymmediaçion que tiene con el santissimo sacram $^{\text {to }}$ que a de llebar en sus brazos se debe considerar de una misma pieza con la custodia de el altissimo a cuia mag $^{\mathrm{d}}$ se debe la ceremonia de el culto exterior de el palio silla ${ }^{48}$.

En cualquier caso, el arzobispo sabía que el medio más eficaz para lograr su cometido era comparecer en la Corte, intención que ya había manifestado en 1679 a pesar de su delicado estado de salud. Un documento hallado entre los papeles de la silla ofrece una relación del periplo burocrático que supuso el paso del prelado a Madrid y el lento progreso del litigio ${ }^{49}$.

El 19 de julio de 1685 se solicitó licencia para que el arzobispo fuera a la Corte a defender el asunto de la silla y otros negocios de su dignidad arzobispal. Este memorial se remitió al confesor regio, el obispo de Sigüenza, quien trató de convencer a Carlos II de que la concediese. El 31 de julio, el rey envió el memorial a la Cámara de Castilla, que en consulta de 1 de agosto determinó que, aunque los motivos eran justos, no convenía que el prelado se ausentase de su diócesis por el desconsuelo que causaría a los fieles. No obstante, Ríos y Guzmán no estaba dispuesto a resignarse y se entregó un nuevo memorial a Carlos II alegando que por derecho natural y positivo cualquier prelado estaba obligado a defender los derechos de su dignidad. Finalmente, se concedió la licencia el 17 de septiembre de 1685 .

Por una carta del deán, y futuro arzobispo, Martín de Ascargorta, sabemos que a principios de diciembre Bernardo llegó a Consuegra (Toledo) "con salud

47. María P. Bertos Herrera, El tema de la Eucaristía en el Arte de Granada y su Provincia I (Granada: Universidad de Granada, 1986), 39-40.

48. AECG, Libros de Archivo, Caja 35, Silla, s.f. El arzobispo Ríos al escribano del Real Acuerdo, 20 de junio de 1685 .

49. AECG, Libros de Archivo, Caja 35, Silla, s.f. Relación de lo sucedido y obrado desde que el arzobispo Ríos pidió licencia para ir a la Corte a defender el negocio de la silla y otros derechos de la dignidad arzobispal. 
y sin quebranto alguno" 50 . Sin embargo, tuvo que esperar hasta el 6 de marzo de 1686 para hablar con el rey y entregarle en mano el manifiesto en defensa de la silla.

El 14 de mayo de 1686, el Consejo de la Cámara decretó que se trajera del Archivo del Consejo Real toda la documentación sobre el particular para tomar una decisión. Sin embargo, este trámite no se ejecutó por diferentes razones. Esta inesperada dilación obligó a que Ríos, a finales de junio, pidiera ayuda al cardenal arzobispo de Toledo, Fernández Portocarrero, para que presionase al presidente del Consejo:

Y aviendose pasado tantos días sin que tenga efecto lo que la cámara tiene acordado, y siguiéndose de esta dilación los yncombenientes, y desabíos, que se dexan reconocer así por la falta que hago en mi yglesia, como por los gastos que me ocasiona la asistencia en esta corte, no escuso noticiar a Vra $\mathrm{Em}^{\mathrm{a}}$ de lo que me pasa, considerando el gran çelo con que $\mathrm{Vra}_{\mathrm{Em}}^{\mathrm{a}}$ a empeçado a faborecer este negocio, cuia protez ${ }^{\text {on }}$ toca a Vra Ema por su dignidad y por quién es, y por ser Vra $\mathrm{Em}^{\mathrm{a}}$ el prinçipal interesado en la observancia desta çeremonia ${ }^{51}$.

Ríos y Guzmán no se iba a quedar de brazos cruzados esperando el veredicto final. Y menos ahora que ya no contaba con el apoyo de su hermano Don Lope, quien había fallecido en $1681^{52}$. Hasta el último momento, el arzobispo recurrió a todo aquel que consideraba útil para afianzar su postura y se valió de todas las pruebas que pudo recopilar. Así, en septiembre preguntó al confesor de la reina, Guillermo Ayrault, en qué posición la confesaba. El fin era rebatir a los oidores la supuesta indecencia que suponía que el prelado se sentase en la procesión. Ayrault confirmó lo que el prelado suponía, esto es, que "la reyna nuestra señora por su grande piedad está de rodillas, yo sentado en tabourete y puesto el bonete" ${ }^{53}$. La idea era que si la propia realeza toleraba que los sacerdotes se sentasen en determinadas funciones eclesiásticas, poco tenían que objetar los oidores. Además, este rendimiento de la potestad real a la eclesiástica, al menos en ciertas ocasiones, como la del sacramento de la penitencia, era una prueba de la gran consideración que se debía al estado eclesiástico.

50. AECG, Legajo $121 \mathrm{f}$ (a), pza. 1, s.f. El deán Martín de Ascargorta al arzobispo Ríos, 4 de diciembre de 1685.

51. AECG, Libros de Archivo, Caja 35, Silla, s.f. El arzobispo Ríos al cardenal arzobispo de Toledo, 30 de junio de 1686.

52. Luis de Salazar y Castro, Catalogo historial genealógico de los Señores y Condes de la casa y villa de Fernanuñez, desde la conquista de Cordova año de 1236 hasta este de 1682 (Madrid: impreso por Lucas Antonio de Bedmar y Baldivia, 1682), 158-159.

53. AECG, Libros de Archivo, Caja 35, Silla, s.f. El confesor de la reina al arzobispo Ríos, 21 de septiembre de 1686. 
El manifiesto de la silla, escrito por Cabrera Núñez, ya había incidido en este aspecto con un episodio semi-fabuloso entre Isabel la Católica y su confesor fray Hernando de Talavera, primer arzobispo de Granada. Según este relato, la primera vez que el fraile confesó a la reina le explicó que debía arrodillarse mientras él permanecía sentado como juez del tribunal de penitencia. Isabel acató el mandato, "posponiendo, y humillando la Magestad a quien representa a Christo" ${ }^{4}$. Además quedó maravillada de la firmeza con que fray Hernando defendió la autoridad de su oficio, describiéndolo a sus damas de compañía como un varón "con valor, y entereza en su exaltación, todo dado a Dios, y todo negado al mundo, sin que le embaracen respetos humanos por soberanos que sean" ${ }^{55}$. En definitiva, a la imagen del arzobispo sumiso a la corona que reivindicaban los oidores, se contraponía la del prelado cuya firmeza en la defensa de su dignidad causaba admiración y orgullo en la realeza. Modelo de prelado que, evidentemente, trataba de reproducir Ríos y Guzmán.

Según la Relación de todo lo sucedido y obrado..., el 12 de enero de 1687 el Consejo de la Cámara consultó a Su Majestad. Una carta que Ríos envió al presidente el 17 de enero, poco después de que la consulta llegase al rey, revela el disgusto del prelado ante la resolución de la Cámara, la cual conocía por diversas filtraciones. En dicha carta, advirtió al presidente de que autorizar la silla en la procesión fuera del claro no era una solución factible ya que

cómo es posible, que en tan grande angostura quepe a la par el prelado rebestido de pontifical, y los dos diáconos revestidos a sus lados (...) y que quede sitio fuera de ella para que vaya la silla pontifical, que por lo menos ocupa una vara de ancho y otra las dos personas que la lleban ${ }^{56}$.

A pesar de todo, ese fue el tenor del veredicto final. Se trata de una sentencia que parece que intentó complacer a ambos litigantes, pero que, realmente, no satisfizo a ninguno. Los esfuerzos de Ríos y Guzmán habían dado sus frutos de forma parcial: al menos, la silla volvía a tener cabida en el recorrido de la procesión. Eso sí, apartada a un lado. Esta medida no puso fin al litigio, el cual, como refiere J.J. López-Guadalupe, se reabrió en la procesión de 1695 con Martín de Ascargorta como arzobispo ${ }^{57}$.

54. Cabrera, Manifiesto en que el ilustríssimo señor don fray Alonso, hh. $69 \mathrm{v}-69 \mathrm{r}$.

55. Cabrera, Manifiesto en que el ilustríssimo señor don fray Alonso, h. 68 r.

56. AECG, Libros de Archivo, Caja 35, Silla, s.f. El arzobispo Ríos al presidente, 17 de enero de 1687.

57. Juan J. López-Guadalupe Muñoz, "Fiesta y litigio en la Granada barroca a propósito de un dibujo de la procesión del Corpus de 1695", Cuadernos de Arte de la Universidad de Granada, no. 34 (2008): 54-56. 


\section{LA DIÓCESIS DE GRANADA DURANTE LA AUSENCIA DEL ARZOBISPO}

El tiempo que Ríos y Guzmán permaneció en Madrid dejó el gobierno de la diócesis en manos del provisor Martín Torrico de Pedrajas, el deán Martín de Ascargorta y el tesorero de la catedral Miguel Muñoz de Ahumada. También encomendó la administración del arzobispado al secretario Bartolomé Sánchez de Valera para que "cuyde de la contaduría de yglesias y firme las nóminas y libranzas y (h)aga los decretos tocantes a la buena expedizion de los negocios" ${ }^{58}$. Y, además, dejó una serie de instrucciones que indicaban cómo se habían gestionado hasta el momento algunos asuntos y marcaban el camino a seguir en otros (adjudicación de púlpitos, becas colegiales, órdenes, licencias para confesar etc.) ${ }^{59}$. En carta de 4 de diciembre de 1685, el deán Ascargorta, entre otras cosas, aludió expresamente a estas disposiciones:

La instrucción que VSIIla fue servido de dejarnos se observa exactissimamente así en las ordenes, como en los exámenes de confessores que es solo lo que hasta ahora se (h)a ofrezido, y para todo nos juntamos lunes, miércoles, y sábado en el Palacio de VSIll ${ }^{\mathrm{a}}$ donde se confiere la más mínima deterrm ${ }^{\text {on }}$ presente el secret ${ }^{\circ}$ de VSIIla ${ }^{60}$.

Ríos y Guzmán mantuvo desde Madrid una fluida relación epistolar con estos individuos. También se carteó con familiares y amigos de confianza como, por ejemplo, el oidor Diego de la Serna. Todos ellos lo mantuvieron al día de las novedades que sucedían en Granada, especialmente las que concernían a la Iglesia.

Uno de los primeros asuntos rastreados en la correspondencia fue la posibilidad de que, tras la muerte del obispo de Córdoba a finales de noviembre de 1685, Ríos y Guzmán fuese propuesto para cubrir la vacante. Ascargorta lamentaba esta posible pérdida con cierto lirismo: "no lastima mi corazón otra cosa sino que sin ser parte VSIlla para resistirlo, nos quiten a VIlla de esta su queridissima esposa" ${ }^{1}$. Mientras que Diego de la Serna consideraba que "aviendo de dexar y aviendo de perder nosotros a VSIll ${ }^{\mathrm{a}}$ es consolable y más que otras partes Cordova (...) pero estando con fixa resoluçion de no pasar a otra parte nada puede ser mexor que Granada" ${ }^{62}$. En efecto, parece que el arzobispo, a sus sesenta años,

58. Archivo Histórico Nacional, Consejos, 15.812, exp. 1-3ํ, f. 16 v.

59. AECG, Legajo 126 f, pza. 11, s.f. Instrucción que dejó el arzobispo Ríos y Guzmán para el gobierno de la diócesis en su ausencia.

60. AECG, Legajo $121 \mathrm{f}$ (a), pza. 1, s.f. El deán Martín de Ascargorta al arzobispo Ríos, 4 de diciembre de 1685.

61. AECG, Legajo 121 f (a), pza. 1, s.f. El deán Martín de Ascargorta al arzobispo Ríos, 11 de diciembre de 1685 .

62. AECG, Legajo 121 f (a), pza. 3, s.f. Diego de la Serna al arzobispo Ríos, 8 de enero de 1686.

Chronica Nova, 46, 2020, 281-308 - http://doi.org/10.30827/cnova.v0i46.7878 
y tras ocho al frente de la archidiócesis granadina, no tenía intención de pasar a un obispado de menor prestigio, aunque de mayor renta.

La ventaja de Diego de la Serna respecto al resto de confidentes era que como oidor de la Chancillería podía revelar al prelado algunas noticias de la institución. En cualquier caso, trató de tranquilizar al arzobispo asegurándole que "en lo que fuere de la Chançillería está muy asegurado el punto de lo ecclessiástico"63. En 1686, Diego de la Serna fue admitido en la Orden de Calatrava y eligió como padrino a Martín de la Cueva, esposo de la sobrina del prelado, pues, tal como confesó a este, "toda Granada sabe quanto debo a VS Ill $^{\mathrm{a}} \mathrm{y}$ culparían mi atención si en la función del hábito no tuviesse $\mathrm{p}^{\text {te }}$ alguno de su familia" ${ }^{64}$. El 9 de julio, el propio Martín de la Cueva escribió a Ríos para comunicarle la celebración de dicha ceremonia de investidura, a la que siguió un imprevisto convite en casa de Diego de la Serna ${ }^{65}$.

Como cabría esperar, la estrecha relación de Diego de la Serna con el prelado no tardó en ser criticada por algunos círculos. En septiembre de dicho año, cuando los trámites en Madrid se habían estancado, escribió a Ríos lo siguiente:

aquí han esparçido alguno o algunos de mis compos que es mío el papel que $\mathrm{VS}^{\mathrm{a}} \mathrm{IIl}^{\mathrm{a}}$ ha dado en Madrid por la silla, y aunque juzgara que me agraviaban en apropiarme papel que no pareçe mío, lo pudiera sentir más porque la ambiçión con que pretenden no para hasta descomponer al que les pareçe les estorva, y esparçen esta voz o pa malquistarme con los de allá, o para enflaqueçer las honras que VS ${ }^{a} \mathrm{Ill}^{\mathrm{a}}$ pudiera haçerme ${ }^{66}$.

Podemos suponer que Serna se refería a ciertos oidores de la Chancillería; quienes, lógicamente, como parte litigante en el pleito, desconfiarían de él por su estrecha relación con el arzobispo. No obstante, no podemos descartar otras posibilidades.

Aparte del negocio de la silla, el arzobispo aprovechó su estancia en la Corte para resolver otros problemas de la iglesia granadina. Por ejemplo, a principios de 1686, Ascargorta comunicó al prelado que el cabildo catedralicio necesitaba fondos para acabar una reforma; asunto que parece que, finalmente, Ríos añadió a sus gestiones ${ }^{67}$. De igual modo, en otra carta, el deán protestó por la poca

63. AECG, Legajo $121 \mathrm{f}$ (a), pza. 3, s.f. Diego de la Serna al arzobispo Ríos, 8 de enero de 1686. 64. AECG, Legajo $121 \mathrm{f}$ (a), pza. 3, s.f. Diego de la Serna al arzobispo Ríos, 14 de mayo de 1686. 65. AECG, Legajo $121 \mathrm{f}$ (b), pza. 4, s.f. Martín de la Cueva al arzobispo Ríos, 9 de julio de 1686. 66. AECG, Legajo $121 \mathrm{f}$ (a), pza. 3, s.f. Diego de la Serna al arzobispo Ríos, 24 de septiembre de 1686.

67. AECG, Legajo 121 f (a), pza. 1, s.f. El deán Ascargorta al arzobispo Ríos, 1 de enero de 1686, 26 de febrero de 1686 y 4 de junio de 1686. 
porción de los diezmos que recibía el clero en comparación con la corona ${ }^{68}$. En su respuesta, el prelado garantizó el tratamiento de esta cuestión en la Corte, para que, al menos, fuera patente la "tenuidad de las rentas" ${ }^{69}$.

Ascargorta también intentó no preocupar demasiado al arzobispo con los problemas cotidianos de la diócesis. Pero en ocasiones no pudo ocultar su disgusto, especialmente cuando se ponía en entredicho su autoridad. En este sentido, se quejó varias veces del talante impetuoso de algunos canónigos, como la ocasión que ni siquiera pudo tratarse en cabildo la propuesta del arzobispo sobre la unión de la Capilla Real por ser "tantos los ascos y desafectos con que se (h)a tomado (sin expresar más razón que disonarles a algunos si (h)an de tener en la iglesia a fulano y fulano)" ${ }^{70}$. Otro suceso que indignó a Ascargorta fue la representación de una comedia en la iglesia de la Concepción a la que había negado expresamente la licencia. Esta irreverencia molestó sobremanera al deán, que no pudo resistir el deseo de contárselo al prelado:

oi confieso que estoi con más calor del que acostumbro: porque quebrándole los ojos a el Deán, llebar las comediantas a un convento a que bueltas las espaldas a el ss ${ }^{\text {mo }}$ sacramento representen una comedia y esto estando VSIlla ausente: se le haze mui sensible a quien tiene tan poca mortificación como io, y no a de defender con pendencias, estas y otras determinaciones ${ }^{71}$.

El 11 de junio de 1686, dos días antes del Corpus, Ascargorta informó al arzobispo de que el procurador general autorizaba de nuevo el uso de las andas. Pero que, dada la inmediatez de la festividad, el cabildo había determinado no reanudar la costumbre sin el acuerdo oficial del prelado. Por tanto, en las procesiones del Corpus y octava de ese año, el Santísimo volvería a salir en las manos del preste ${ }^{72}$. En carta de 18 de junio, el arzobispo mostró su conformidad y manifestó sus ánimos:

doy a VM las graçias de lo dispuesto, y del travaxo de aquel día el q1 pase con arto desconsuelo por no hallarme en la prozesion de esa çiu ${ }^{\mathrm{d}}$ en la forma que yo pensaba, y así mismo me desconsoló ver en esta corte la prozesion muy diferente de cómo se celebra en esa çiu ${ }^{\mathrm{d}}$ espero en Dios que el año que viene a de estar

68. AECG, Legajo $121 \mathrm{f}$ (a), pza. 1, s.f. El deán Ascargorta al arzobispo Ríos, 11 de junio de 1686. 69. AECG, Legajo $121 \mathrm{f}$ (a), pza. 1, s.f. El arzobispo Ríos al deán Ascargorta, 18 de junio de 1686.

70. AECG, Legajo 121 f (a), pza. 1, s.f. El deán Ascargorta al arzobispo Ríos, 22 de enero de 1686.

71. AECG, Legajo 121 f (a), pza. 1, s.f. El deán Ascargorta al arzobispo Ríos, 26 de febrero de 1686.

72. AECG, Legajo 121 f (a), pza. 1, s.f. El deán Ascargorta al arzobispo Ríos, 11 de junio de 1686.

Chronica Nova, 46, 2020, 281-308 - http://doi.org/10.30827/cnova.v0i46.7878 
resuelta esta controversia de forma que la dignidad y la ygla no pierdan nada de su decoro ${ }^{73}$.

Entre muchos otros incidentes relatados por el deán, destaca un nuevo conflicto de precedencias con el poder civil a mediados de 1687. Esta vez los protagonistas no fueron los oidores, sino el corregidor. Según cuenta Ascargorta, el corregidor se sorprendió de que en la misa se diera la paz al pertiguero antes que a él y pidió explicaciones. En lugar de dejarle las cosas claras desde el principio, seguramente para evitar un airado conflicto, "se le alentó a que por ser mala ceremonia se reformaría a contemplación de la ciudad" "74. Así, el corregidor propuso la cuestión en su cabildo y llegó legacía al catedralicio. Pese al talante conciliador inicial, el deán contestó que, en realidad, era razonable que se diera la paz en primer lugar al pertiguero por ser ministro de altar y que, además, él no podía alterar las ceremonias eclesiásticas. Sin embargo, el cabildo municipal insistió en que debía darse la paz antes al corregidor y caballeros veinticuatros que al pertiguero y acólitos con ciriales. Ascargorta no estaba dispuesto a ceder ni un ápice en este asunto, pues aunque a priori no revestía mayor importancia, implicaba la intromisión del poder civil en cuestiones exclusivamente eclesiásticas. Con esta determinación se dirigió al prelado:

represento a VSIll ${ }^{\text {a }}$ que si consigue la Ciudad esto a(h)ora, y no se deja olvidar, pedirá mañana velas, zeniza, y palmas antes que los Pertigueros y nos enrredamos en muchos inconvenientes: la costumbre en esto es regla inalterable y así si VSIll ${ }^{\mathrm{a}}$ fuere servido podrá mandar que se escriba a el Cavildo diciendo VSIIla que sin estar VSIlla aquí y enterarse de las razones de una y de otra parte no se tome resolución, porque la dignidad de VSIlla no podrá consentir que como sale para VSIIll $^{\mathrm{a}}$ paz del altar, salga sola para la Ciudad siendo legos ${ }^{75}$.

A mediados de junio de 1687, el arzobispo, que todavía estaba en la Corte, recibió una carta de Diego de la Serna en la que achacaba el corrimiento y dolor de ciática que padecía el prelado al "temple de Madrid diverso del de Gran ${ }^{\mathrm{da}}$, la fatiga de litigante, y poca commodidad estando de passo" ${ }^{76}$. No sabemos con exactitud cuándo regresó a Granada, pero el cinco de agosto de 1687 ya se encontraba en la ciudad, donde despachó reverendas ad examinandum a José Pimentel, clérigo de menores ordenes natural de Granada y residente en Sevilla ${ }^{77}$.

73. AECG, Legajo $121 \mathrm{f}$ (a), pza. 1, s.f. El arzobispo Ríos al deán Ascargorta, 18 de junio de 1686.

74. AECG, Legajo $121 \mathrm{f}$ (b), pza. 4, s.f. El deán Ascargorta al arzobispo Ríos, 3 de junio de 1687.

75. AECG, Legajo $121 \mathrm{f}$ (b), pza. 4, s.f. El deán Ascargorta al arzobispo Ríos, 3 de junio de 1687.

76. AECG, Legajo $121 \mathrm{f}$ (b), pza. 4, s.f. Diego de la Serna al arzobispo Ríos, 15 de junio de 1687.

77. AECG, Libros de Archivo, Caja 24, Libro de registro de órdenes (1678-1693), ff. 88 r- 89 v. 
Según Garrido Atienza, el arzobispo sufrió un achaque de perlesía en las fiestas del Corpus de $1688^{78}$. ¿Evitaría la ausencia del arzobispo en la procesión los roces con la Chancillería?

\section{EL CORPUS DE 1688: NUEVA FUENTE DE PROBLEMAS}

El 17 de junio de 1688 dos alguaciles de la Chancillería detuvieron la procesión del Corpus en el Zacatín, poco antes de llegar a la bocacalle de la Cerería. Se trataba de una parada habitual, aceptada a regañadientes por la Iglesia, hasta que pasara el Real Acuerdo en dirección a la catedral para incorporarse a la procesión. Sin embargo, esta vez el Real Acuerdo se retrasó más de lo normal y prolongó la detención sobre una hora. Esta insólita paralización de la procesión llevó a que algunos ministros eclesiásticos acudiesen al lugar para ver qué pasaba y protagonizaron un altercado con los alguaciles. Nuevamente, un desencuentro entre la jurisdicción eclesiástica y la real por un asunto de precedencias que empañó el Corpus y, esta vez, alteró el orden de la comitiva procesional ${ }^{79}$. Pasado el día, tanto la Chancillería como el Arzobispado iniciaron una investigación y algunos de sus protagonistas y testigos declararon ante el oidor Diego de la Serna y el provisor Martín Torrico de Pedrajas. Esta última información, compuesta por treinta y dos testigos y realizada entre el 21 de junio y el 7 de julio de 1688, es la fuente empleada para aproximarnos al suceso ${ }^{80}$.

Los hombres que llevaban la tarasca y los gigantes, artefactos que daban principio a la procesión, fueron los primeros en detenerse a instancia de los alguaciles Bernabé de Juano y Alonso de Zamora. Por la declaración de Toribio de Coro, alcaide de la Alhóndiga Zaida, sabemos que siete montañeses llevaban la tarasca y otros siete los gigantes. También que dichos alguaciles les prohibieron el paso con la amenaza de quinientos ducados y dos años de presidio. La presencia en Granada de los montañeses, gentes procedentes de Galicia, Asturias y Cantabria, se remonta a los tiempos de la conquista. Pero, como apunta LópezGuadalupe, fueron un grupo reducido que no tomó verdadera carta de naturaleza

78. Miguel Garrido Atienza, Antiguallas granadinas. Las fiestas del Corpus (Granada: Imprenta de José López Guevara, 1889), 145.

79. Garrido Atienza refiere la organización de la procesión del Corpus: la encabezaban la tarasca y los gigantes, a los que seguían los priostes, mayordomos y oficiales de las cofradías, tras ellos los beneficiados, curas y sacristanes de los pueblos, el clero secular de las parroquias de Granada, las comunidades regulares, el cabildo catedral, la Custodia, el arzobispo, la comitiva arzobispal, el Real Acuerdo y Ciudad; y, por último, a modo de escolta, la tropa. Garrido, Antiguallas, 108-120.

80. AECG, Libros de Archivo, Caja 35, Silla, s.f. Información hecha por el provisor Martín Torrico de Pedrajas sobre la detención de la procesión del Corpus el año de 1688.

Chronica Nova, 46, 2020, 281-308 - http://doi.org/10.30827/cnova.v0i46.7878 
hasta finales del siglo XVII ${ }^{81}$. Tal como se observa en los testimonios de la presente información, los montañeses formaban parte del engranaje del mundo comercial granadino como trabajadores en la plaza y en las aduanas. Tareas que debieron complementar con otro tipo de encargos puntuales como este que les proporcionaban un ingreso económico adicional ${ }^{82}$.

La detención de la procesión se hizo patente en la catedral cuando acababa de salir la comunidad de los carmelitas, sin poder proseguir las de San Agustín, San Francisco y Santo Domingo. José Eugenio de Luque, primer maestro de ceremonias, dice que encontró en el altar mayor al preste —el deán Martín de Ascargorta-, al diácono y subdiácono, a quienes sugirió volver a la sacristía o sentarse en el presbiterio. Asimismo, los canónigos, revestidos con sus capas pluviales, se sentaron en el coro. Circunstancias que según José Martínez, beneficiado de San Cecilio que portaba el palio, "extrañaron mucho el testigo y sus compañeros porque no se (h)a hecho en otra ocasión". Asimismo, Andrés Cachorro, cura de San Matías que llevaba las andas aseguró "que esta detención (...) no la ha visto este declarante en otros años que (h)a salido con la mesma ocupación por lo qual fue muy reparable y zensurada".

Eugenio de Luque, primer maestro de ceremonias, sigue contando que el canónigo más antiguo le culpó de la situación y le dijo que su deber era "ir con las cruzes y hacer que pasasen sin embargo de cualquiera detención que se lo impidiese". Por tanto, salió de la catedral y se dirigió a la bocacalle de la Cerería. Una vez allí, instó a los montañeses a que prosiguieran el recorrido, pero estos se negaron, amedrentados por las amenazas de los alguaciles. De modo que Luque decidió atravesar la calle del Zacatín, que estaba repleta de cofrades con sus velas y estandartes, y encontró a los clérigos con las cruces de las iglesias parroquiales a la altura de la plaza de Bib-Rambla. Sin pensárselo dos veces, exhortó a los sacristanes con las cruces a que pasasen entre los cofrades y la tarasca, que permanecían quietos, hasta la bocacalle de la Cerería. Se trataba de una estrategia inteligente, pues los ministros de la Chancillería no tenían jurisdicción sobre los eclesiásticos y con mayor dificultad embarazarían su paso. De hecho, Juan de Moya, segundo maestro de ceremonias, asegura que "los ministros reales que allí estaban dijeron que con las cruzes no se podían meter porque eran clérigos los que las llevaban".

81. Los montañeses pertenecieron a la cofradía de Nuestra Señora y San Roque desde la construcción de la ermita por sus antepasados que participaron en la Conquista. Pero en 1702 se escindieron y decidieron fundar la cofradía de carácter nacional de Nuestra Señora de Covadonga, con una clara alusión a su lugar de procedencia. Miguel L. López-Guadalupe Muñoz, "La Hermandad de Nuestra Señora de Covadonga, de asturianos y montañeses, de Granada (1702-1810)", Chronica nova: Revista de historia moderna de la Universidad de Granada, no. 18 (1990): 242-245.

82. Garrido Atienza nos habla de un expediente de 1652 que contiene el contrato con los "mancebos montañeses" para llevar los carros de la representación, así como la tarasca y los gigantes. Garrido, Antiguallas, 19-20. 
En ese momento, llegaron a dicha bocacalle el fiscal eclesiástico, Manuel de la Fuente, y un notario arzobispal que, según la declaración de Toribio de Coro, "porque no querían andar quitó un rótulo de un gigante y lo hechó en el suelo y al montañés que lo llevaba le dio un arempujón [sic]".

La procesión reanudó su marcha, ahora encabezada por los sacristanes con las cruces parroquiales. El fiscal eclesiástico animó a los cofrades a que las siguieran, pero, como refiere el hortelano Antonio González, cofrade de Nuestro Señor Resucitado, "al tiempo de llegar el testigo y sus hermanos a pasar adelante los dichos ministros levantaron las baras como haciendo acción de darles con ellas para detenerlos y notificaron el auto". En efecto, los cofrades escapaban a la inmunidad eclesiástica y, consiguientemente, los alguaciles les dijeron, "que no pasasen que eran unos pobres hombres seculares y que los conozian muy bien a todos" ${ }^{83}$. Los hortelanos, conscientes del peligro al que se exponían, decidieron apagar las velas y abandonar la procesión por los callejones del Zacatín. Las dos cofradías que iban detrás, la de San Antón del gremio de cordoneros y la de Santa Lucía de maestros zapateros, siguieron su ejemplo y también se fueron. A propósito, Pedro García, maestro zapatero, señala que "aviendo pasado las cruzes y religiones no tenían lugar en la prozesión donde yr".

Casi todas las declaraciones coinciden en que hubo un intercambio de reproches entre los alguaciles y el fiscal eclesiástico, momento en el que este exclamó que "(h)abia de subzeder en el Zacatín de Granada lo que no sucedería en Ynglaterra".

El alcaide de la Alhóndiga Zaida, que iba con los montañeses, cuenta que habiendo empezado a pasar las comunidades regulares, el fiscal les pidió que apartasen la tarasca y los gigantes. Entonces, el testigo fue a buscar a Francisco Romero, uno de los comisarios de la fiesta; quien le dijo "que pues que avia ya enmpezado a pasar la procesión la dejasen pasar toda y después bolviesen detrás della a proseguir con dicha tarasca y jigantes y los llevasen hasta la yglesia como es costumbre".

El encuentro entre la procesión y el Real Acuerdo se produjo a la altura de Plaza Nueva. Juan de Salazar, caballero veinticuatro, se encontraba allí con Pedro Guiruela y Antonio Moreno, receptor de la Chancillería, cuando se produjo el suceso. Salazar declara que vieron bajar los caballos de los ministros que acompañaban al Real Acuerdo por la calle de San Gil hacia Plaza Nueva al mismo tiempo que, desde el Zacatín, salían los sacristanes con las cruces a la misma plaza. Guiruela añade que Alonso de la Paz, el primer ministro que iba a caballo, levantó la vara y gritó a los sacristanes, quienes se detuvieron por un instante, mientras que otros ministros fueron a informar al presidente y

83. Declaración de Francisco Dávila Ponce de León, clérigo de menores órdenes de la orden de Santiago. AECG, Libros de Archivo, Caja 35, Silla, s.f.

Chronica Nova, 46, 2020, 281-308 - http://doi.org/10.30827/cnova.v0i46.7878 
oidores de lo que ocurría. Parece que el Real Acuerdo no se atrevió a transgredir la inmunidad eclesiástica que protegía a las cruces y para evitar un escándalo público decidió retroceder e ir por otras calles a la lonja, donde se apearon de los caballos.

El presidente y los oidores ocuparon su puesto habitual en la procesión, que transcurrió sin más incidentes. Una procesión de Corpus que se diferenció de la de otros años en su duración y composición, pero que no dejó de ser escenario habitual de los desencuentros entre la Chancillería y la jurisdicción eclesiástica.

A pesar de las informaciones que realizaron la Chancillería y el Arzobispado parece que el suceso no tuvo mayor trascendencia. Es cierto que los alguaciles de la Chancillería no impidieron el paso a los religiosos y únicamente amenazaron a los seglares, pero en cierto modo desnaturalizaron la procesión al despojarla de algunas de sus partes. Las cofradías, además de estar obligadas a participar, tal como estipulaban las Ordenanzas de $1552^{84}$, reimpresas en 1670 , estaban vinculadas a la procesión por una razón devocional. Aunque, como señala Garrido Atienza, los gremios fueron eximiéndose de esta obligación ${ }^{85}$. Esto último podría explicar que en la presente información solo se citen tres cofradías gremiales y que ni siquiera guarden el orden que establecen las ordenanzas. Menos grave fue con seguridad la retirada de la tarasca y los gigantes, que, a pesar de formar parte de un programa moralizante, su carácter lúdico nunca terminó de ser bien visto por la Iglesia y, finalmente, fueron prohibidos en 1780 .

\section{CONCLUSIONES}

Los desencuentros entre el Arzobispo y la Chancillería de Granada fue un mal inevitable dado el entramado jurídico del siglo XVII. Esta competencia se agravó, primero por el patronato regio sobre la Iglesia de Granada, y segundo por el ímpetu regalista de muchos oidores al que el arzobispado contestó con un intento de reafirmación de la autoridad episcopal. Esta rivalidad fue plenamente evidente en los actos y ceremonias públicos por el afán de ambos cuerpos por remarcar su prestigio y autoridad. Ni el Real Acuerdo ni el Arzobispo dejaron pasar ninguna cuestión de precedencia que pudiese suponer cierta superioridad respecto al otro. Ni siquiera en la muerte; pues, por ejemplo, el Real Acuerdo decidió no asistir al funeral de Ríos y Guzmán por considerar que el túmulo excedía los honores propios de su dignidad ${ }^{86}$.

84. Garrido, Antiguallas, 102.

85. Garrido, Antiguallas, 109.

86. López, Retratos y semblanzas, 181-182. 
La silla del arzobispo en la procesión del Corpus fue uno de los símbolos más célebres de este pulso entre ambas instituciones. Su reivindicación fue una forma de subrayar la autoridad del arzobispo y, por ende, la jurisdicción eclesiástica. Pero en la vida de los prelados granadinos jugó un papel más profundo que trascendió la obligación institucional y la soberbia personal. La defensa de la silla encubrió un verdadero interés por estar a la altura del modelo de prelado triunfante en el imaginario eclesiástico y popular. Así, muchos arzobispos se implicaron en dicho pleito con el objetivo de demostrar su valía y capacidad de liderazgo y, en consecuencia, lograr una buena imagen personal que perdurase en la memoria de la iglesia granadina.

\section{BIBLIOGRAFÍA}

Echeverría, Juan de. Paseos por Granada y sus contornos, ó descripción de sus antigüedades y monumentos, dados a luz por el célebre Padre Juan de Echevarría, por los años de 1764 y ahora nuevamente reimpresos é ilustrados con algunas pequeñas notas. Granada: Imprenta Nueva de Valenzuela, 1814. Egido López, Teófanes. "El real patronato". En Iglesia y sociedad en el reino de Granada (ss. XVI-XVIII), editado por Miguel L. López-Guadalupe Muñoz, Antonio Lara Ramos y Antonio L. Cortés Peña, 9-21. Granada: Universidad de Granada, 2003.

Escolano y Ledesma, Diego. Memorial a la reyna nuestra señora. Por don Diego Escolano... sobre el uso de la silla en la processión del Corpus. Granada: s.n., 1669.

Bertos Herrera, María P. El tema de la Eucaristía en el Arte de Granada y su Provincia I. Granada: Universidad de Granada, 1986.

Cabrera Núñez de Guzmán, Melchor de. Manifiesto en que el ilustríssimo señor don fray Alonso Bernardo de los Ríos y Guzmán, Arçobispo de Granada, funda, que el llevar en la processión del día del Corpus silla, almohada, y lienço, con la Familia necessaria, y ocupar el claro frente de la Custodia, y Tabernáculo, es ceremonia observada de tiempo inmemorial. Madrid: s.n., 1684.

Cortés Peña, Antonio L. "Un conflicto jurisdiccional en el declive del Santo Oficio". En Iglesia y Sociedad en el reino de Granada (ss. XVI-XVIII), editado por Antonio L. Cortés Peña, Miguel L. López-Guadalupe Muñoz y Antonio Lara Ramos, 189-201. Granada: Universidad de Granada, 2003.

— "Fray Alonso Bernardo de los Ríos y Guzmán, un arzobispo del Barroco". Boletín de la Real Academia de Córdoba de Ciencias, Bellas Letras y Nobles Artes, no. 154 (2008): 205-214.

Gan Giménez, Pedro. "En torno al Corpus granadino del siglo XVII". Chronica nova: Revista de historia moderna de la Universidad de Granada, no. 17 (1989): 91-130. 
- "Los prebendados de la Iglesia granadina: una bio-bibliografía". Revista del Centro de Estudios Históricos de Granada y su Reino, no. 4 (1990): 139-212.

- "Aspectos de la iglesia granadina en el siglo XVII". En Andalucía Moderna: actas del II Congreso de Andalucía (Andalucía Moderna I), coordinado por el Instituto de Historia de Andalucía, 431-437. Córdoba: Publicaciones de la consejería de cultura de la Junta de Andalucía y obra social y cultural Cajasur, 1995.

García Bernal, José J. El fasto público en la España de los Austrias. Sevilla: Universidad de Sevilla, 2006.

Garrido Arredondo, José. "Los recursos de fuerza a través de la práctica judicial del siglo XVII en la Chancillería de Granada". En Iglesia y Sociedad en el reino de Granada (ss. XVI-XVIII), editado por Antonio L. Cortés Peña Miguel L. López-Guadalupe Muñoz y Antonio Lara Ramos, 93-106. Granada: Universidad de Granada, 2003.

Garrido Atienza, Miguel. Antiguallas granadinas. Las fiestas del Corpus. Granada: Imprenta de José López Guevara, 1889.

Golfín de Ulloa, Pedro. Al rey nuestro señor. Los luminares mayor, y menor, que representan las dos jurisdicciones, y potestades, espiritual, y temporal. Granada: Imprenta Real de Francisco Sánchez, 1670.

Gómez González, Inés. "El ceremonial de la justicia en la Granada del setecientos". En Vida cotidiana en la España de la Ilustración, coordinado por Inmaculada Arias de Saavedra Alías, 313-332. Granada: Universidad de Granada, 2012.

León Vegas, Milagros. "Rivalidad de preeminencias entre el cabildo civil y eclesiástico en los cortejos procesionales del Corpus Christi. Antequera (siglo XVI)". En Poder, sociedad, religión y tolerancia en el mundo hispánico, de Fernando el Católico al siglo XVIII, coordinado por Eliseo Serrano Martín y Jesús Gascón Pérez, 1859-1873. Zaragoza: Institución Fernando el Católico, 2018.

Leturia Ibarrondo, Félix. "Conflicto en Corpus Christi: escándalos ceremoniales o secuencias rituales". Kobie Serie Antropología Cultural, no. 18 (2014): 111-134.

López, Miguel A. Los arzobispos de Granada. Retratos y semblanzas. Granada: Arzobispado de Granada, 1993.

López-Guadalupe Muñoz, Juan J. "Fiesta y litigio en la Granada barroca a propósito de un dibujo de la procesión del Corpus de 1695". Cuadernos de Arte de la Universidad de Granada, no. 39 (2008): 49-64.

López-Guadalupe Muñoz, Miguel L. "La Hermandad de Nuestra Señora de Covadonga, de asturianos y montañeses, de Granada (1702-1810)". Chronica nova: Revista de historia moderna de la Universidad de Granada, no. 18 (1990): 237-266. 
- "Jurisdicción real y jurisdicción eclesiástica: El "Auxilio de la fuerza" en la Granada del Seiscientos". En Violencia y conflictividad en el universo barroco, coordinado por Julián J. Lozano Navarro y Juan L. Castellano, 301-344. Granada: Comares, 2010.

- "Cofradías y devociones populares en el convento de Santa Cruz la Real de Granada". Revista de Humanidades, no. 27 (2016): 141-161.

Martínez Medina, Francisco J. "Sacerdocio y Reino en la Edad Moderna. Una Iglesia nacional: el Patronato Regio desde la perspectiva histórica. Una Iglesia nacional". En Religión y poder en la Edad Moderna, editado por José L. Beltrán Moya, Antonio L. Cortés Peña y Eliseo Serrano Martín, 37-51. Granada: Universidad de Granada, 2005.

Muñoz de Ahumada, Miguel. Soberana señora. A vuestra protección D.C.O. El deán, y cabildo de la $S^{\text {ta }}$ Yglesia... sobre los excesos cometidos por algunos Racioneros de dicha Santa Yglesia. Granada: s.n., 1670.

Rois y Mendoza, Francisco de. Constituciones promulgadas por... D. Fr. Francisco de Roys y Mendoza... obispo de Badajoz, electo arzobispo de Granada...en la santa synodo que celebró dominica de sexagésima primero de Febrero de 1671 años. Madrid: impreso por José Fernández de Buendía, 1673.

Salazar y Castro, Luis de. Catálogo historial genealógico de los Señores y Conde de la casa y villa de Fernanuñez, desde la conquista de Cordova año de 1236 hasta este de 1682. Madrid: Lucas Antonio de Bedmar y Baldivia, 1682.

Sanz Serrano, María. "La procesión del Corpus en Sevilla. Influencias sociales y políticas en la evolución del cortejo". Ars longa: cuadernos de arte, no. 16 (2007): 55-72.

Ximénez Lobatón, Diego, y Pedro Sarmiento y Toledo. Señor. A los reales pies de V.M. ponen este discurso jurídico... sobre no aver cumplido D. Diego Escolano, arzobispo de esta ciudad, las reales cédulas de V.M. en que se le mandó no sacasse silla, almohada, y salvilla en la procession del día del Corpus. Granatae: ex Typographia Regia, 1670. 